\title{
Expression of tryptophan hydroxylase in gastric mucosa in symptomatic and asymptomatic Helicobacter pylori infection
}

Cezary Chojnacki ${ }^{1}$, Tomasz Popławski², Aleksandra Błońska ${ }^{1}$, Janusz Błasiak², Marek Romanowski ${ }^{3}$, Jan Chojnacki ${ }^{1}$

\author{
Department of Clinical Nutrition and Gastroenterological Diagnostics, \\ Medical University of Lodz, Lodz, Poland \\ ${ }^{2}$ Department of Molecular Genetics, University of Lodz, Lodz, Poland \\ ${ }^{3}$ Department of Gastroenterology, Medical University of Lodz, Lodz, Poland
}

Submitted: 8 September 2016

Accepted: 18 January 2017

Arch Med Sci 2019; 15, 2: 416-423

DOI: https://doi.org/10.5114/aoms.2018.76928

Copyright (c) 2018 Termedia \& Banach

\section{Abstract}

Introduction: Helicobacter pylori infection induces clinical symptoms in 15-20\% of subjects, and the reason for this variation is still not clear. The aim of the present study is to evaluate the expression of tryptophan hydroxylase $(\mathrm{TpH}-1)$ in gastric mucosa of patients with symptomatic and asymptomatic $H$. pylori infection in relation to the intensity of bacterial colonization and severity of dyspeptic symptoms.

Material and methods: Ninety subjects (aged 35-49 years) were enrolled in the study and separated into 3 groups of 30 subjects each. Group I - healthy volunteers without $H$. pylori infection, group II - subjects with asymptomatic H. pylori infection, group III $-H$. pylori-infected patients with dyspeptic symptoms, mainly fasting and nocturnal epigastric pain. To diagnose $H$. pylori infection the urea breath test (UBT-13C) and histological analysis were performed. The level of mRNA expression of tryptophan hydroxylase $(\mathrm{TpH}-1)$ was estimated in gastric mucosa with RT-PCR.

Results: The expression of this enzyme in antral mucosa was $2.69 \pm 0.97$ in group I, $2.28 \pm 0.69$ in group $\|(p>0.05)$ and $4.40 \pm 1.64$ in group III $(p<0.001)$. The levels of expression of TpH-1 in gastric body mucosa were $2.16 \pm 0.70,1.57 \pm 0.52(p>0.05)$ and $3.40 \pm 1.51$ ( $p<0.001)$, respectively. In group III a positive correlation was found between intensity of $H$. pylori colonization and $\mathrm{TpH}-1$ expression as well as between $\mathrm{TpH}-1$ expression and severity of dyspeptic symptoms.

Conclusions: Increased expression of $\mathrm{TpH}-1$ in gastric mucosa plays a role in pathogenesis of chronic dyspepsia.

Key words: gastric mucosa, Helicobacter pylori, tryptophan hydroxylase, chronic dyspepsia.

\section{Introduction}

Helicobacter pylori infection is still an important worldwide medical problem. Despite progress in the diagnostics and therapy, in various regions of the world it affects more than half of the population. In the majority of cases (about $80 \%$ ) it is asymptomatic, but discrepancies in the assessment result from the differences in the diagnostic procedures. In population studies, serological methods and determination of the level

\author{
Corresponding author: \\ Prof. Jan Chojnacki \\ Department of Clinical \\ Nutrition and \\ Gastroenterological \\ Diagnostics \\ Medical University of Lodz \\ Plac Hallera 1 \\ 90-647 Łódź, Poland \\ Phone: +48 426393049 \\ Fax: +48 426393049 \\ E-mail: \\ gastrologia@umed.lodz.pl
}


of IgA/lgG [1-4] or IgM antibodies are used most commonly [5], whereas monoclonal stool antigen tests and PCR methods are applied less frequently [6-8]. However, the urea breath test $-{ }^{13} \mathrm{C}-U B T$ - has been recognized to be sufficiently accurate and simple to use in screening of patients [9-11].

Long-term clinical observations indicate that this is not an innocent infection. Its possible consequences include malabsorption of iron and vitamins, secretory dysfunction of the pancreas and intestinal myoelectric activity disorders [12-16]. Moreover, it leads to destructive changes in the gastric and duodenal mucosa and can be the cause of asymptomatic peptic ulcers [17-19]. In asymptomatic infections eradication of $H$. pylori is a preventive management of gastric cancer, especially in patients with a family history of this disease [20-22].

Another issue is to explain why $H$. pylori infection induces clinical symptoms in only $15-20 \%$ of subjects. It was believed to depend on the virulence of $H$. pylori strains, but in many studies conducted in patients with symptomatic and asymptomatic infection, there were no significant differences in the prevalence of virulent CagA and VacA strains [23-28], although there is still a search for them $[29,30]$. Moreover, no morphological differences have been found in gastric mucosa or in the level of pro-inflammatory cytokines [31-33].

However, it has been indicated that impaired oxygen metabolism is observed in asymptomatic infection [34, 35], and the presence or absence of signs of infection depends on many factors, including epigenetic ones - complex interactions between bacteria and the host and environmental factors [36, 37]. Cigarette smoking and the use of nonsteroidal anti-inflammatory drugs can cause inflammation exacerbation [38-40]. There are no consistent views on the impact of dietary components and alcohol on this process [41, 42].

In general, it can be concluded that external gastrotoxic factors or deficiency of enteroprotective factors may adversely affect the natural history of chronic gastritis in patients infected with H. pylori.

From among gastroprotective agents melatonin plays an important role [43]. In dyspeptic patients, particularly with epigastric pain syndrome, its synthesis in gastric mucosa and serum level are decreased [44-47]. The role of serotonin in the pathogenesis of dyspepsia is less known. Patients with dyspepsia without $H$. pylori infection had elevated serum serotonin levels and increased urinary excretion of its metabolite (5-HIAA) $[48,49]$. However, the concentration of serotonin at the site of its synthesis is more important, where as a tissue hormone it exhibits high physiological activity.
In the gastrointestinal tract the main source of serotonin is enterochromaffin cells in which the exogenous L-tryptophan is converted to serotonin involving tryptophan hydroxylase (TpH-1) [50]. Serotonin secretion is stimulated by various factors, including the cholinergic and adrenergic system, nutrients, chemical compounds, bacterial toxins and others [51]. The effect of $H$. pylori infection on this process is not understood.

The aim of the study is to evaluate the expression of tryptophan hydroxylase in gastric mucosa of patients with symptomatic and asymptomatic $H$. pylori infection in relation to the intensity of bacterial colonization and severity of dyspeptic symptoms.

\section{Material and methods}

\section{Patients}

The study included 90 subjects (61 women and 29 men), aged 35-49 years, divided into three groups: - group I (control, $n=30$ ) - healthy volunteers without $H$. pylori infection and without gastrointestinal tract pathology;

- group II $(n=30)$ - subjects with asymptomatic H. pylori infection;

- group III $(n=30)-H$. pylori-infected patients with dyspeptic symptoms, mainly fasting and nocturnal epigastric pain.

All patients underwent endoscopic examination of the upper gastrointestinal tract and histological assessment was performed using hematoxylin-eosin and Giemsa staining. In order to confirm $H$. pylori infection the urea breath test $\left({ }^{13} \mathrm{C}-\right.$ UBT) was applied.

Inclusion criteria: superficial infection of gastric mucosa (grades 1 and 2 according to the Sydney Classification [52], the presence of bacteria in preparations stained by Giemsa, the lambda ratio $(\Delta)$ - more than $4 \% 30$ min after the marker ingestion, using the urease breath test on a FANCl-2 system (Fisher Instruments, Germany), symptoms of minimum 6-month duration and no improvement after antacid or prokinetic drugs.

Exclusion criteria: other organic, metabolic and mental diseases, previous abdominal surgery, receiving any medication, smoking, alcohol abuse.

\section{Study design and procedures}

The severity of dyspeptic symptoms was estimated with the Visual Analog Scale (VAS; 1-10 points).

Laboratory tests included blood cell count, C-reactive protein, glycosylated hemoglobin, bilirubin, alanine and aspartate aminotransferase, $\gamma$-glutamyl transpeptidase, alkaline phosphatase, amylase, lipase, urea, creatinine, cholesterol (HDL and $\mathrm{LDL})$, and triglycerides. 
Seven days prior to the evaluations, all medications were withdrawn and the same diet was used by all subjects with a similar daily amount of products rich in L-tryptophan.

Patients with a symptomatic $H$. pylori infection were subjected to 14-day antibacterial treatment with: pantoprazole $(2 \times 40 \mathrm{mg})$, amoxicillin $(2 \times 1000 \mathrm{mg})$, levofloxacin $(2 \times 500 \mathrm{mg})$. The follow-up ${ }^{13} \mathrm{C}$-UBT test and control endoscopy with biopsy of the same parts of the stomach were

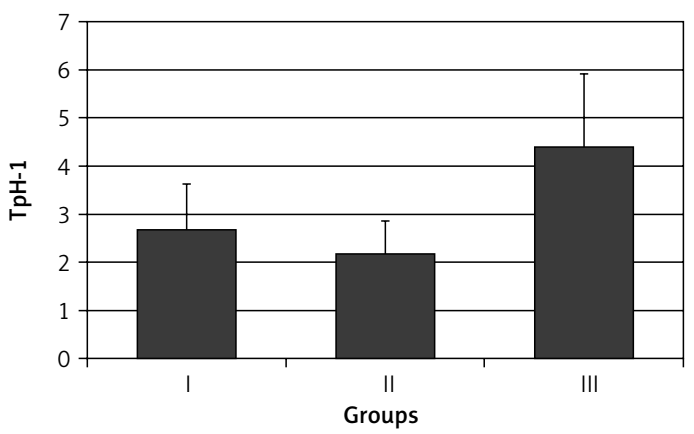

Figure 1. Expression of tryptophan hydroxylase $(\mathrm{TpH}-1)$ in antral gastric mucosa in healthy volunteers (group I), subjects with asymptomatic (group II) and those with symptomatic (group III) Helicobacter pylori infection. Statistical differences: I vs. II $p>0.05$; I vs. III $p<0.001$; II vs. III $p<0.001$

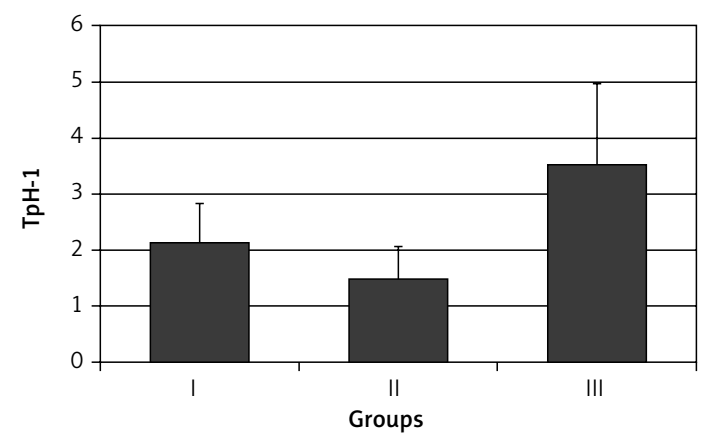

Figure 2. Expression of tryptophan hydroxylase $(\mathrm{TpH}-1)$ in body gastric mucosa in healthy volunteers (group I), subjects with asymptomatic (group II) and those with symptomatic (group III) Helicobacter pylori infection. Statistical differences: I vs. II $p>0.05$; I vs. III $p<0.001$; II vs. III $p<0.001$

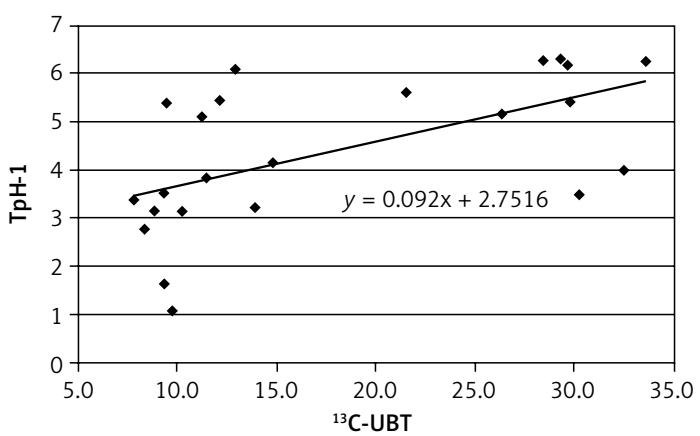

Figure 3. Correlation between intensity of Helicobacter pylori infection $\left({ }^{13} \mathrm{C}-\mathrm{UBT}\right)$ and expression of tryptophan hydroxylase $(\mathrm{TpH}-1)$ in antral gastric mucosa; $r=0.575, p<0.05$ performed 12 weeks after the end of the treatment.

Material for histological and molecular examinations was collected from the antral part (4 samples) and the upper part of the gastric body (4 samples).

The level of mRNA was estimated with RT-PCR and qPCR and, for this purpose, $50 \mathrm{mg}$ of gastric tissue was used. Gastric tissue was excised and placed immediately in RNAlater reagent (Qiagen, Valencia, CA, USA) according to the manufacturer's instructions. For processing, samples were removed from RNAlater and the RNA pellet was reconstituted in $100 \mu \mathrm{l}$ of RNase- and DNasefree water and processed with the RNeasy Mini Kit (Qiagen) according to the manufacturer's RNA Cleanup protocol with DNase I treatment (Qiagen). Purified RNA samples were stored at $-20^{\circ} \mathrm{C}$ until use. The quantity and quality of RNA were evaluated spectrophotometrically. The cDNA synthesis was performed with oligo (dT) using the ImProm-II Reverse Transcription System (Promega, Madison, WI, USA) according to the manufacturer's instructions. The qPCR was conducted with PCR Master Mix (Promega) and specific primers to amplify fragments of the cDNA of the tryptophan hydroxylase $(\mathrm{TpH}-1)$ genes. The qPCR products were separated on an $8 \%$ polyacrylamide gel stained with ethidium bromide. The products were then subjected to densitometry to determine the level of analyzed genes' mRNA. Expression of the housekeeping hypoxanthine phosphoribosyltransferase (HPRT) gene was used to normalize the level of $\mathrm{TpH}-1$ expression.

\section{Statistical analysis}

The non-parametric Kruskal-Wallis test was used for the comparison of $\mathrm{TpH}-1$ expression levels and results of ${ }^{13} \mathrm{C}$-UBT. The Mann-Whitney $U$ test was applied for median comparison. The correlation between the above parameters and intensity of $\mathrm{H}$. pylori infection and severity of epigastric pain was assessed by Pearson's correlation coefficient and the linear regression equation. Excel 2007 and Statistica 9.1 (license no. AXAP 106E7359M-F) software were used for statistical analysis.

\section{Results}

Compared to healthy subjects (group I) $\mathrm{TpH}-1$ expression in antral mucosa in patients with asymptomatic $H$. pylori infection was similar $2.69 \pm 0.97$ and $2.28 \pm 0.69$, respectively $(p>0.05)$.

Higher expression of $\mathrm{TpH}-1$ in this part of the stomach was found in patients with symptomatic infection (group III): $4.40 \pm 1.64(p<0.001)$ (Figure 1). 


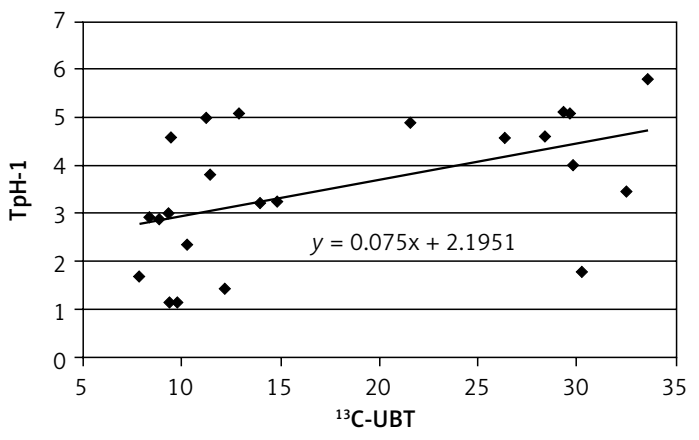

Figure 4. Correlation between intensity of Helicobacter pylori infection $\left({ }^{13} \mathrm{C}-\mathrm{UBT}\right)$ and expression of tryptophan hydroxylase $(\mathrm{TpH}-1)$ in body gastric mucosa; $r=0.4993, p>0.05$

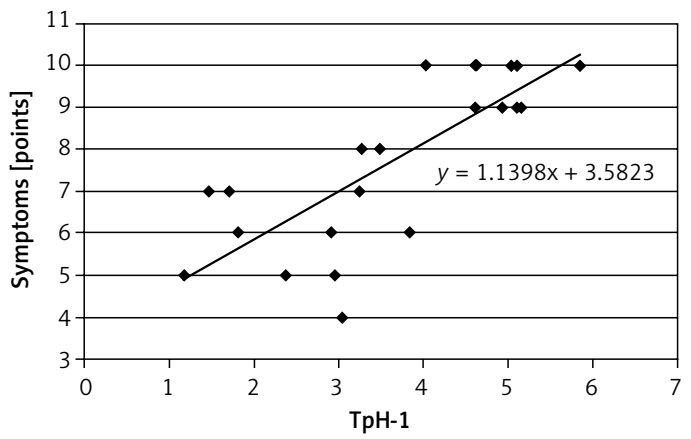

Figure 6. Correlation between expression of tryptophan hydroxylase (TpH-1) in antral gastric mucosa and severity of dyspeptic symptoms; $r=0.8019$, $p<0.001$

The expression of $\mathrm{TpH}-1$ in the gastric body mucosa was: $2.16 \pm 0.70$ in group I, $1.57 \pm 0.52$ in group II $(p>0.05)$, and $3.40 \pm 1.51$ in group III $(p<0.001)$ (Figure 2).

A positive correlation was found between results of ${ }^{13} \mathrm{C}$-UBT and $\mathrm{TpH}-1$ expression in antral $(r=0.575$, Figure 3$)$ and less in gastric body mucosa $(r=0.499$, Figure 4$)$ in patients with symptomatic infection (group III), probably caused by different intensity of $H$. pylori colonization.

In group II, the correlation between the results of ${ }^{13} \mathrm{C}$-UBT and $\mathrm{TpH}-1$ expression in antral and gastric body mucosa was lower $(r=0.529$, $r=0.455$, respectively).

A positive correlation was observed between $\mathrm{TpH}-1$ expression in antral $(r=0.855$; Figure 5) and gastric body mucosa and the intensity of dyspeptic symptoms $(r=0.802$; Figure 6$)$.

Eradication of $\mathrm{H}$. pylori was obtained in $23 \mathrm{pa}$ tients $(76.6 \%)$. In these patients the expression of TpH-1 decreased from $4.40 \pm 1.64$ to $2.51 \pm 0.47$ $(p<0.001)$ in antral mucosa and from $2.28 \pm 0.69$ to $1.69 \pm 0.39$ in gastric body mucosa $(p<0.05)$ (Figure 7).

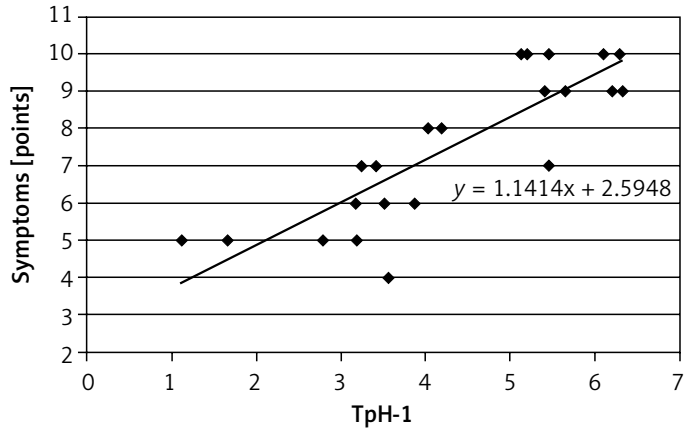

Figure 5. Correlation between expression of tryptophan hydroxylase (TpH-1) in antral gastric mucosa and severity of dyspeptic symptoms; $r=0.8549$, $p<0.01$

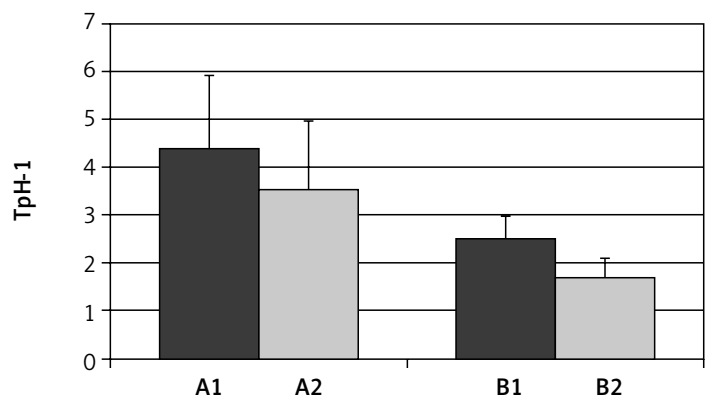

Figure 7. Expression of tryptophan hydroxylase $(\mathrm{TpH}-1)$ in antral (A) and body (B) gastric mucosa, before (A1, B1) and after (A2, B2) eradication of Helicobacter pylori. Differences in both parts of gaster are statistically significant; A1 vs. A2 $p<0.01$; B1 vs. B2 $p<0.001$

After 3 months dyspeptic symptoms were absent in $9(39.1 \%)$ patients, decreased to a varying degree in $8(34.8 \%)$ patients, and did not change in $6(26.1 \%)$ patients.

\section{Discussion}

Serotonin contents in the alimentary tract constitute approximately $90 \%$ of the total body pool of this hormone. In normal conditions it is secreted along the whole tract, mainly by enterochromaffin cells [53-56]. However, in inflammatory foci other cells may also be its source [57-59].

The effects of serotonin on the gastrointestinal tract depend on the type of the stimulated receptor. So far seven classes of serotonin receptors have been identified - from 5-HT1 to 5-HT7 - within which several subtypes can be distinguished [60].

Gastric motility is stimulated by activation of 5-HT2, 5-HT3 and 5-HT4 receptors, but it is inhibited by the 5-HT1 receptor. Stimulation of the $5-\mathrm{HT} 1 \mathrm{~A}$ receptor causes fundus relaxation, whereas 5 -HT1p receptors are involved in the initiation of peristalsis and gastric secretion $[61,62]$. 
5-HT3 receptors are located in the gastrointestinal tract, mainly on vagal sensory fibers which convey stimuli from the gastrointestinal tract to the central nervous system. Activation of $5-\mathrm{HT} 3$ is responsible for the occurrence of visceral hypersensitivity, early satiety, nausea and vomiting $[63,64]$. Serotonin plays a special role in the mechanisms of visceral sensation. Nerve impulses arising within the gastrointestinal tract after reaching the brain are transmitted to the limbic system - which is responsible for the motivational-affective component of visceral pain, such as anxiety, suffering, and emotions - and to the sensory cortex, where pain is located and consciously perceived $[65,66]$.

The mechanism of the onset of dyspeptic symptoms in $H$. pylori-infected subjects is complex and still unclear. The pain usually occurs upon fasting and at night but often also after meals, and it is not accompanied by early satiety or food retention. Studies to date have not demonstrated in these cases adverse effects of serotonin on gastric motility and secretion [67-69]. Factors that induce visceral pain include, among others, mechanical stimuli and inflammatory mediators (cytokines, prostaglandins). Serotonin with the main participation of 5 -HT3 receptors plays a role as a neurotransmitter in transmitting visceral sensation, regardless of the nature of excitatory stimuli [70, 71].

Helicobacter pylori infection causes chronic gastritis with different activity. Inflammatory and destructive changes of gastric mucosa are the result of the adverse effect of bacterial cytotoxins and increased secretion of pro-inflammatory cytokines [72-74]. Eradication of bacteria results in lower levels of cytokines [75] but it does not always relieve dyspeptic symptoms. Likewise, it is not known why $H$. pylori colonization triggers dyspeptic symptoms only in some infected subjects. Precise knowledge of serotonin synthesis and metabolism may be the key to explain these differences. Serotonin is an important mediator of inflammation, promotes the chemotaxis of granulocytes, lymphocytes, macrophages to inflammatory foci and enhances the secretion of pro-inflammatory cytokines [76, 77].

The results of our study indicate that the expression of tryptophan hydroxylase in the gastric mucosa with symptomatic $H$. pylori infection is significantly higher than in patients without symptoms. It may indicate the direct induction of $\mathrm{TpH}-1$ by pro-inflammatory cytokines. Cytokines may also cause proliferation of different cells, including enterochromaffin cells. An increased number of them was found previously in $\mathrm{H}$. pylori-infected patients [53].

Downregulation of $\mathrm{TpH}-1$ after $\mathrm{H}$. pylori eradication indicates the role of the bacteria in the disturbances of serotonin homeostasis in the stomach.
However, the level of expression of tryptophan hydroxylase may depend on many factors, including the number of enterochromaffin cells [78], $\mathrm{TpH}-1$ gene polymorphism [79] or the presence of antibodies directed against this enzyme [80].

Regardless of the mechanism, the increase in the level of serotonin can be the cause of visceral pain in various parts of the gastrointestinal tract. It was observed, among other things, that hyperserotoninemia occurring in the appendix was manifested by chronic pain in the lower right abdomen [81]. The effect may vary depending on the density, type and structure of serotonin receptors.

Apart from $H$. pylori eradication the agents that inhibit gastric secretion are used in the treatment of pain in functional dyspepsia. When improvement is not observed, agents modulating the serotonergic system, including psychotropic drugs, are used. Good results were obtained when applying low doses of tricyclic antidepressants [82]. In recent years, serotonin reuptake inhibitors have been used but no consistent results have been obtained. Together with good evaluation [83, 84], there predominate conclusions that these drugs are not more effective than placebo $[85,86]$. Their effect is to increase the concentration of serotonin in the gastrointestinal tract, which in the first phase of the treatment may increase abdominal pain and induce nausea and diarrhea. The risk of gastrointestinal bleeding related to platelet dysfunction is a limitation in the use of SSRIs [87-89]. On the other hand, these drugs are thought to possess antioxidant, anti-inflammatory and gastroprotective properties [90-92].

Assessment of the effectiveness of drugs that modulate the activity of the serotonergic system is difficult because they depend on both the effect on the structure of the gastrointestinal tract and on the CNS $[93,94]$. Chronic dyspepsia is often an exponent of somatization of the depression and the use of SSRIs is justified, but their application requires careful analysis of the patient's health. This group of drugs is heterogeneous, and the majority of them, besides inhibiting serotonin reuptake, exhibit agonist/antagonist activity in relation to various serotonin receptors.

In view of the above information, a new class of drugs selectively inhibiting $\mathrm{TpH}-1$ is the hope for successful treatment of certain forms of dyspepsia and other disorders of the gastrointestinal tract $[95,96]$. The results of current, mainly experimental studies are optimistic, but require extended clinical trials.

In conclusion, this study demonstrates that increased expression of $\mathrm{TpH}-1$ in gastric mucosa plays an important role in pathogenesis of chronic dyspepsia. 


\section{Acknowledgements}

The approval of the Ethics Committee of the Medical University of Lodz (RNN/596/11/KB) and patients' written consent were obtained to perform the study. The study was supported by the Polish Ministry of Science and Higher Education (NN4025437/40) and conducted in accordance with the principles of the Declaration of Helsinki and Good Clinical Practice.

\section{Conflict of interest}

The authors declare no conflict of interest.

\section{References}

1. Biernat MM, Poniewierka E, Błaszczuk J, et al. Antimicrobial susceptibility of Helicobacter pylori isolates from Lower Silesia, Poland. Arch Med Sci 2014; 10: 505-9.

2. Matusiak M, Chałubiński M, Broncel $M$, et al. Putative consequences of exposure to Helicobacter pylori infection in patients with coronary heart disease in terms of humoral immune response and inflammation. Arch Med Sci 2016; 12: 45-54.

3. Jais M, Barua S. Seroprevalence of anti Helicobacter pylori lgG/lgA in asymptomatic population from Delhi. J Commun Dis 2004; 36: 132-5.

4. Dinić M, Tasić G, Stanković-Dordević D, Otasević L, Tasić M, Karanikolic A. Serum anti-Helicobacter pylori IgA and IgG antibodies in asymptomatic children in Serbia. Scand J Infect Dis 2007; 39: 303-7.

5. Sumona AA, Hossain MA, Musa AK, et al. Anti H. pylori IgM in symptomatic and asymptomatic population. Mymensingh Med I 2009; 18: 18-20.

6. Dube C, Nkosi TC, Clarke AM, Mkwetshana N, Green E, Ndip RN. Helicobacter pylori antigenemia in an asymptomatic population of Eastern Cape Province, South Africa: public health implications. Rev Environ Health 2009; 24: 2492-55.

7. Mishra S, Singh V, Rao GR, Dixit VK, Gulati AK, Nath G. Prevalence of Helicobacter pylori in asymptomatic subjects: a nested PCR based study. Infect Genet Evol 2008; 8: 815-9.

8. Yazdanbod A, Salimian S, Habibzadeh S, et al. Effect of Helicobacter pylori eradication in Iranian patients with functional dyspepsia: a prospective, randomized, placebo-controlled trial. Arch Med Sci 2015; 11: 964-9.

9. Rothenbacher D, Bode G, Peschke F, Berg G, Adler G, Brenner $\mathrm{H}$. Active infection with Helicobacter pylori in an asymptomatic population of middle aged to elderly people. Epidemiol Infect 1998; 120: 297-303.

10. Shaikh S, Khaled MA, Islam A, Kurpad AV, Mahalanabis D. Evaluation of stool antigen test for Helicobacter pylori infection in asymptomatic children from a developing country using 13C-urea breath test as a standard. J Pediatr Gastroenterol Nutr 2005; 40: 552-4.

11. Michel A, Pawlita M, Boeing H, Gissmann L, Waterboer T. Helicobacter pylori antibody patterns in Germany: a cross-sectional population study. Gut Pathog 2014; 6: 10.

12. Annibale B, Marignani M, Monarca B, et al. Reversal of iron deficiency anemia after Helicobacter pylori eradication in patients with asymptomatic gastritis. Ann Intern Med 1999; 131: 668-72.

13. Mahalanabis D, Islam MA, Shaikh S, et al. Haematological response to iron supplementation is reduced in chil- dren with asymptomatic Helicobacter pylori infection. Br J Nutr 2005; 94: 969-75.

14. Naja F, Kreiger N, McKeown Eyssen G, Allard J. Bioavailability of vitamins $\mathrm{E}$ and $\mathrm{C}$ : does Helicobacter pylori infection play a role? Ann Nutr Metab 2010; 56: 253-9.

15. López de Romaña D, Pizarro F, Diazgranados D, Barba A, Olivares M, Brunser O. Effect of Helicobacter pylori infection on iron absorption in asymptomatic adults consuming wheat flour fortified with iron and zinc. Biol Trace Elem Res 2011; 144: 1318-26.

16. Domínguez-Muñoz JE, Malfertheiner P. Effect of Helicobacter pylori infection on gastrointestinal motility, pancreatic secretion and hormone release in asymptomatic humans. Scand I Gastroenterol 2001; 36: 1141-7.

17. Vaira D, Miglioli M, Mulè P, et al. Prevalence of peptic ulcer in Helicobacter pylori positive blood donors. Gut 1994; 35: 309-12.

18. Menegatti $\mathrm{M}$, Holton J, Figura $\mathrm{N}$, et al. Clinical significance of Helicobacter pylori seropositivity and seronegativity in asymptomatic blood donors. Dig Dis Sci 1998; 43: 2542-8.

19. Ecclissato C, Carvalho AF, Ferraz JG, de Nucci G, De Souza CA, Pedrazzoli J Jr. Prevalence of peptic lesions in asymptomatic, healthy volunteers. Dig Liver Dis 2001; 33: 403-6.

20. Talley NJ, Fock KM, Moayyedi P. Gastric cancer consensus conference recommends Helicobacter pylori screening and treatment in asymptomatic persons from high-risk populations to prevent gastric cancer. Am J Gastroenterol 2008; 103: 510-4.

21. den Hoed CM, van Eijck BC, Capelle LG, et al. The prevalence of premalignant gastric lesions in asymptomatic patients: predicting the future incidence of gastric cancer. Eur J Cancer 2011; 47: 1211-8.

22. Ford AC, Forman D, Hunt RH, Yuan Y, Moayyedi P. Helicobacter pylori eradication therapy to prevent gastric cancer in healthy asymptomatic infected individuals: systematic review and meta-analysis of randomised controlled trials. BMJ 2014; 348: 3174.

23. Shyu RY, Jiang SY, Lai CH, Hsu CT, Young TH, Yeh MY. High frequency of cytotoxin-associated gene $\mathrm{A}$ in $\mathrm{He}$ licobacter pylori isolated from asymptomatic subjects and peptic ulcer patients in Taiwan. J Clin Gastroenterol 1998; 27: 54-9.

24. Go MF, Graham DY. Presence of the cagA gene in the majority of Helicobacter pylori strains is independent of whether the individual has duodenal ulcer or asymptomatic gastritis. Helicobacter 1996; 1: 107-11.

25. Elitsur Y, Neace C, Werthammer MC, Triest WE. Prevalence of CagA, VacA antibodies in symptomatic and asymptomatic children with Helicobacter pylori infection. Helicobacter 1999; 4: 100-5.

26. Sarker SA, Nahar S, Rahman M, et al. High prevalence of cagA and vacA seropositivity in asymptomatic Bangladeshi children with Helicobacter pylori infection. Acta Paediatr 2004; 93: 1432-6.

27. Sicinschi LA, Correa P, Bravo LE, et al. Non-invasive genotyping of Helicobacter pylori cagA, vacA, and hopQ from asymptomatic children. Helicobacter 2012; 17: 96-106.

28. Hirai I, Sasaki T, Kimoto A, Fujimoto S, Moriyama T, Yamamoto Y. Assessment of East Asian-type cagA-positive Helicobacter pylori using stool specimens from asymptomatic healthy Japanese individuals. J Med Microbiol 2009; 58: 1149-53.

29. Molnar B, Galamb O, Sipos F, Leiszter K, Tulassay Z. Molecular pathogenesis of Helicobacter pylori infection: the role of bacterial virulence factors. Dig Dis 2010; 28 : 604-8. 
30. Blanchard TG, Czinn SJ, Correa P, et al. Genome sequences of 65 Helicobacter pylori strains isolated from asymptomatic individuals and patients with gastric cancer, peptic ulcer disease, or gastritis. Pathog Dis 2013; 68: 39-43.

31. Russo F, Jirillo E, Clemente C, et al. Circulating cytokines and gastrin levels in asymptomatic subjects infected by Helicobacter pylori (H. pylori). Immunopharmacol Immunotoxicol 2001; 23: 13-24.

32. Klupińska G, Chojnacki C, Knopik-Dabrowicz A, Wojtuń S, Stec-Michalska K. Estimation of gastric mucosa morphological changes in subjects with asymptomatic Helicobacter pylori infection and family history of gastric cancer. Pol Merkur Lekarski 2004; 17 Suppl 1: 142-4.

33. Saha DR, Datta S, Chattopadhyay S, et al. Indistinguishable cellular changes in gastric mucosa between Helicobacter pylori infected asymptomatic tribal and duodenal ulcer patients. World J Gastroenterol 2009; 15: 1105-12.

34. Felley CP, Pignatelli B, Van Melle GD, et al. Oxidative stress in gastric mucosa of asymptomatic humans infected with Helicobacter pylori: effect of bacterial eradication. Helicobacter 2002; 7: 342-8.

35. Walecka-Kapica E, Knopik-Dabrowicz A, Klupińska G, Chojnacki J. The assessment of nitric oxide metabolites in gastric juice in Helicobacter pylori infected subjects in compliance with grade of inflammatory lesions in gastric mucosa. Pol Merkur Lekarski 2008; 24: 95-100.

36. Delahay RM, Rugge M. Pathogenesis of Helicobacter pylori infection. Helicobacter 2012; Suppl 1: 9-15.

37. Cid TP, Fernández MC, Benito Martínez S, Jones NL. Pathogenesis of Helicobacter pylori infection. Helicobacter 2013; Suppl 1: 12-7.

38. Khan MA, Ghazi HO. Helicobacter pylori infection in asymptomatic subjects in Makkah, Saudi Arabia. J Pak Med Assoc 2007; 57: 114-7.

39. González CA, López-Carrillo L. Helicobacter pylori, nutrition and smoking interactions: their impact in gastric carcinogenesis. Scand J Gastroenterol 2010; 45: 6-14.

40. Ghosh P, Bodhankar SL. Association of smoking, alcohol and NSAIDs use with expression of cag $A$ and cag T genes of Helicobacter pylori in salivary samples of asymptomatic subjects. Asian Pac J Trop Biomed 2012; 2: 479-84.

41. Liu H, Merrell DS, Semino-Mora C, et al. Diet synergistically affects Helicobacter pylori-induced gastric carcinogenesis in nonhuman primates. Gastroenterology 2009; 137: 1367-79.

42. Wang MY, Yue JY, Zhang YX, Liu XD, Gao XZ. Helicobacter pylori infection in asymptomatic HBV carriers, alcohol users and normal adult population in Shandong Province, China. Clin Res Hepatol Gastroenterol 2011; 35: 560-2.

43. Klupińska G, Popławski T, Smigielski J, Błasiak J, Chojnacki J. The effect of melatonin on oxidative DNA damage in gastric mucosa cells of patients with functional dyspepsia. Pol Merkur Lekarski 2009; 26: 366-9.

44. Chojnacki C, Poplawski T, Blasiak J, Chojnacki J, Klupinska G. Does melatonin homeostasis play a role in continuous epigastric pain syndrome? Int J Mol Sci 2013; 14: 12550-62.

45. Chojnacki C, Popławski T, Blasiak J, Chojnacki J, Reiter RJ, Klupinska G Expression of melatonin synthesizing enzymes in Helicobacter pylori infected gastric mucosa. Biomed Res Int 2013; 2013: 845032.

46. Klupińska G, Chojnacki C, Harasiuk A, et al. Nocturnal secretion of melatonin in subjects with asymptomat- ic and symptomatic Helicobacter pylori infection. Pol Merkur Lekarski 2006; 21: 239-42.

47. Chojnacki C, Poplawski T, Klupinska G, Blasiak J, Chojnacki J, Reiter RJ. Secretion of melatonin and 6-sulfatoxymelatonin urinary excretion in functional dyspepsia. World J Gastroenterol 2011; 17: 2646-51.

48. Harasiuk A, Klupińska G, Walecka-Kapica E, et al. Secretion of serotonin and melatonin in patients with functional dyspepsia. Pol Merkur Lekarski 2007; 22: 336-40.

49. Wiśniewska-Jarosińska M, Harasiuk A, Klupińska G, Śmigielski J, Stec-Michalska K, Chojnacki C. Diagnostic value of measuring serum serotonin and urinary 5 -hydroxyindoleacetic acid concentration in the diagnosis of functional dyspepsia. Prz Gastroenterol 2010; 5: 285-91.

50. Boadle-Biber MC Regulation of serotonin synthesis. Prog Biophys Mol Biol 1993; 60: 1-15.

51. Tyce GM. Origin and metabolism of serotonin. J Cardiovasc Pharmacol 1990; 16 Suppl 3: S1-7.

52. Dixon MF, Genta RM, Yardley JH, Correa P. Histological classification of gastritis and Helicobacter pylori infection: an agreement at last? The International Workshop on the Histopathology of Gastritis. Helicobacter 1997; Suppl 1: S17-24.

53. Kulig G, Klupińska G, Jochymski C, Wiśniewska-Jarosińska M, Kozłowski W, Chojnacki J. Evaluation of the number of enterochromaffin cells in gastric mucosa in subjects with functional dyspepsia. Pol Merkur Lekarski 2009; 26: 370-2.

54. Gershon MD. Localization and neurochemical aspects of serotonin in the gut. In: Serotonin and Gastrointestinal Function. Boca Raton, Florida, CRC Press 1995; 11-31.

55. Meyer T, Brinck U. Differential distribution of serotonin and tryptophan hydroxylase in the human gastrointestinal tract. Digestion 1999; 60: 63-8.

56. Racke K, Reimann A, Schwörer H, Kilbinger H. Regulation of 5-HT release from enterochromaffin cells. Behav Brain Res 1995; 73: 83-7.

57. Nowak EC, de Vries VC, Wasiuk A, et al. Tryptophan hydroxylase-1 regulates immune tolerance and inflammation. J Exp Med 2012; 209: 2127-35.

58. Kritas SK, Saggini A, Cerulli G, et al. Relationship between serotonin and mast cells: inhibitory effect of anti-serotonin. J Biol Regul Homeost Agents 2014; 28: 377-80.

59. Maeda T, Miura Y, Fukuda K, Hayashi S, Kurosaka M. Decoy receptor 3 regulates the expression of tryptophan hydroxylase 1 in rheumatoid synovial fibroblasts. Mol Med Rep 2015; 12: 5191-6.

60. Hoyer D, Martin G. 5-HT receptor classification and nomenclature: towards a harmonization with the human genome. Neuropharmacology 1997; 36: 419-28.

61. Hansen MB. Neurohumoral control of gastrointestinal motility. Physiol Res 2003; 52: 1-30.

62. Mawe GM, Gershon MD. The $5-\mathrm{HT}_{1}$ receptor. Drug News Perspect 1993; 6: 24-30.

63. Gershon MD, Tack J. The serotonin signaling system: from basic understanding to drug development for functional G1 disorders. Gastroenterology 2007; 132: 397-414.

64. Kim DY, Camilleri M. Serotonin: a mediator of the braingut connection. Am J Gastroenterol 2000; 95: 2698-709.

65. Derbyshire SW. Visceral afferent pathways and functional brain imaging. Sci World J 2003; 3: 1065-80.

66. Camilleri M. Serotonergic modulation of visceral sensation: lower. Gut 2002; 51: 81-6.

67. Johansen B, Bech K. BRL 24924, a 5-hydroxytryptamine type 3 antagonist, and gastric secretion of acid and pepsin in vivo. Digestion 1991; 48: 121-7. 
68. Lepard KJ, Chi J, Mohammed JR, et al. Gastric antisecretory effect of serotonin: quantitation of release and site of action. Am J Physiol 1996; 271: 669-77.

69. Manes G, Dominguez-Muñoz JE, Leodolter A, Malfertheiner P. Effect of cisapride on gastric sensitivity to distension, gastric compliance and duodeno-gastric reflexes in healthy humans. Dig Liver Dis 2001; 33: 407-13.

70. Drossman DA. Functional abdominal pain syndrome. Clin Gastroenterol Hepatol 2004; 2: 353-365.

71. Carvero F. Visceral pain-central sensitization. Gut 2000; 47: 56-7.

72. Michalkiewicz J, Helmin-Basa A, Grzywa R, et al. Innate immunity components and cytokines in gastric mucosa in children with Helicobacter pylori infection. Mediators Inflamm 2015; 2015: 176726.

73. Bagheri N, Azadegan-Dehkordi F, Shirzad M, et al. Mucosal interleukin-21 mRNA expression level is high in patients with Helicobacter pylori and is associated with the severity of gastritis. Cent Eur J Immunol 2015; 40: 61-7.

74. Lin Q, Xu H, Che X, Tang G, Gu L, Wang Y. Helicobacter pylori cytotoxin-associated gene A activates tumor necrosis factor-alpha and interleukin- 6 in gastric epithelial cells through P300/CBP-associated factor-mediated nuclear factor-KB p65 acetylation. Mol Med Rep 2015; 12: 6337-45.

75. Rossi AF, Cadamuro AC, Biselli-Périco JM, et al. Interaction between inflammatory mediators and miRNAs in Helicobacter pylori infection. Cell Microbiol 2016; 18: 1444-58.

76. Ghia Je, Li N, Wang $\mathrm{H}$, et al. Serotonin has a key role in pathogenesis of experimental colitis. Gastroenterology 2009; 137: 1649-60.

77. Shajib MS, Khan Wl. The role of serotonin and its receptors in activation of immune responses and inflammation. Acta Physiol (Oxf) 2015; 213: 561-74.

78. Gut P, Czarnywojtek A, Fischbach J, et al. Chromogra $\operatorname{nin} A$ - unspecific neuroendocrine marker. Clinical utility and potential diagnostic pitfalls. Arch Med Sci 2016; 12: $1-9$.

79. Zhang ZF, Duan ZJ, Wang LX, Yang D, Zhao G, Zhang L. The serotonin transporter gene polymorphism (5-HTTLPR) and irritable bowel syndrome: a meta-analysis of 25 studies. BMC Gastroenterol 2014; 14: 23.

80. Scarpa R, Alaggio R, Norberto L, et al. Tryptophan hydroxylase autoantibodies as markers of a distinct autoimmune gastrointestinal component of autoimmune polyendocrine syndrome type 1. J Clin Endocrinol Metab 2013; 98: 704-12.

81. Dhillon AP, Rode J. Serotonin and its possible role in the painful non-inflamed appendix. Diagn Histopathol 1983; 6: 239-46.

82. Talley NJ, Locke GR, Saito YA, et al. Effect of amitriptyline and escitalopram on functional dyspepsia: a multicenter, randomized controlled study. Gastroenterology 2015; 149: 340-9.

83. Itatsu T, Nagahara A, Hojo $M$, et al. Use of selective serotonin reuptake inhibitors and upper gastrointestinal disease. Intern Med 2011; 50: 713-7.

84. Korendovych IV, Svintsits'kyı̆ AS, Revenok KM, Maliarov SO. Psychopharmacological approach with the usage of selective serotonin reuptake inhibitors in functional dyspepsia treatment. Lik Sprava 2014; 11: 58-64

85. Tan VP, Cheung TK, Wang WM, Pang R, Wong BC. Treatment of functional dyspepsia with sertraline: a dou ble-blind randomized placebo-controlled pilot study. World Gastroenterol 2012; 18: 6127-33.
86. Talley NJ. Functional dyspepsia: new insights into pathogenesis and therapy. Korean J Intern Med 2016; 31: 444-56.

87. Yamaguchi T, Hidaka N, Suemaru K, Araki H. The coadministration of paroxetine and low-dose aspirin synergistically enhances gastric ulcerogenic risk in rats. Biol Pharm Bull 2008; 31: 1371-5.

88. Yamamoto T, Abe K, Kuyama Y. Selective serotonin reuptake inhibitor and gastrointestinal hemorrhage. Nihon Rinsho 2013; 71: 751-6.

89. Dall M, Schaffalitzky de Muckadell OB, Møller Hansen J, et al. Helicobacter pylori and risk of upper gastrointestinal bleeding among users of selective serotonin reuptake inhibitors. Scand J Gastroenterol 2011; 46: 1039-44.

90. Dursun H, Bilici M, Albayrak F, et al. Antiulcer activity of fluvoxamine in rats and its effect on oxidant and antioxidant parameters in stomach tissue. BMC Gastroenterol 2009; 9: 36.

91. Saxena B, Singh S. Investigations on gastroprotective effect of citalopram, an antidepressant drug against stress and pyloric ligation induced ulcers. Pharmacol Rep 2011; 63: 1413-26.

92. Ji CX, Fan DS, Li W, et al. Evaluation of the anti-ulcerogenic activity of the antidepressants duloxetine, amitriptyline, fluoxetine and mirtazapine in different models of experimental gastric ulcer in rats. Eur J Pharmacol 2012; 691: 46-51.

93. Gershon MD. Serotonin is a sword and a shield of the bowel: serotonin plays offense and defense. Trans Am Clin Climatol Assoc 2012; 123: 268-80.

94. O'Mahony S, Dinan TG, Keeling PW, Chua AS. Central serotonergic and noradrenergic receptors in functional dyspepsia. World J Gastroenterol 2006; 12: 2681-7.

95. Liu Q, Yang Q, Sun W, et al. Discovery and characterization of novel tryptophan hydroxylase inhibitors that selectively inhibit serotonin synthesis in the gastrointestinal tract. J Pharmacol Exp Ther 2008; 325: 47-55.

96. Kim JJ, Wang H, Terc JD, Zambrowicz B, Yang QM, Khan WI. Blocking peripheral serotonin synthesis by telotristat etiprate (LX1032/LX1606) reduces severity of both chemical- and infection-induced intestinal inflammation. Am J Physiol Gastrointest Liver Physiol 2015; 309: 455-65. 